\title{
Effects of Historical Land-Cover Changes on Flooding and Sedimentation, North Fish Creek, Wisconsin
}

\author{
By Faith A. Fitzpatrick', James C. Knox ${ }^{2}$, and Heather E. Whitman ${ }^{1}$ \\ 'U.S. Geological Survey, Water Resources Division; 'University of Wisconsin-Madison, Department of Geography
}

\begin{abstract}
North Fish Creek, a Wisconsin tributary to Lake Superior, is an important recreational fishery that is potentially limited by the loss of aquatic habitat caused by accelerated flooding and sedimentation. A study of the historical flooding and sedimentation characteristics of North Fish Creek was done to determine how North Fish Creek responded to human-caused changes in land cover since European settlement of the region in the 1870's. Geomorphic field evidence combined with hydrologic and sediment-transport modeling indicate that historical clear-cut logging, followed by agricultural activity, significantly altered the hydrologic and geomorphic conditions of North Fish Creek. The geomorphic responses to land-cover changes were especially sensitive to the location of reaches along the main stem and on the timing of large floods.

On the basis of geomorphic evidence in flood-plain deposits and abandoned channels, the size offloods and sedimentloads increased in North Fish Creek after conversion of forested land to cropland and pasture. Changes in channel characteristics were particularly noticeable after record floods in 1941 and 1946. The upper main stem channel bed eroded downward at least 3 meters and the channel capacity at least doubled after European settlement. In the lower main stem, the post-settlement sedimentation rate on the flood plain and in the channel is 4 to 6 times pre-settlement rates. The water
\end{abstract}

table also appears to be rising near the mouth of North Fish Creek, perhaps consistent with (1) elevated local streambed elevations caused by sedimentation and (2) a slow relative rise in the local level of Lake Superior due to crustal rebound from glaciation. Along a transitional reach of the main stem between the upper and lower main stem, there is evidence of accelerated flood-plain sedimentation initially following European settlement. Since at least the 1940's, however, the channel bed in the transitional reach has eroded about 1 meter and the channel capacity has at least doubled.

Results from hydrologic and sediment-transport modeling indicate that modern flood peaks and sediment loads in North Fish Creek may be double that expected under pre-settlement forest cover. During maximum agricultural activity in the mid-1920's to mid-1930's, flood peaks probably were about 3 times larger and sediment loads were about 5 times larger than expected under pre-settlement forest cover. These results indicate that future changes from pasture or cropland to forest will help reduce flood peaks, thereby reducing erosion and sedimentation. The addition of detention basins (to decrease flood peaks) on tributaries to North Fish Creek, or bank and instream restoration (to decrease erosion) in the upper main stem, also may help reduce the contribution of sediment from the upper main stem to the transitional section and lower main stem of the creek.

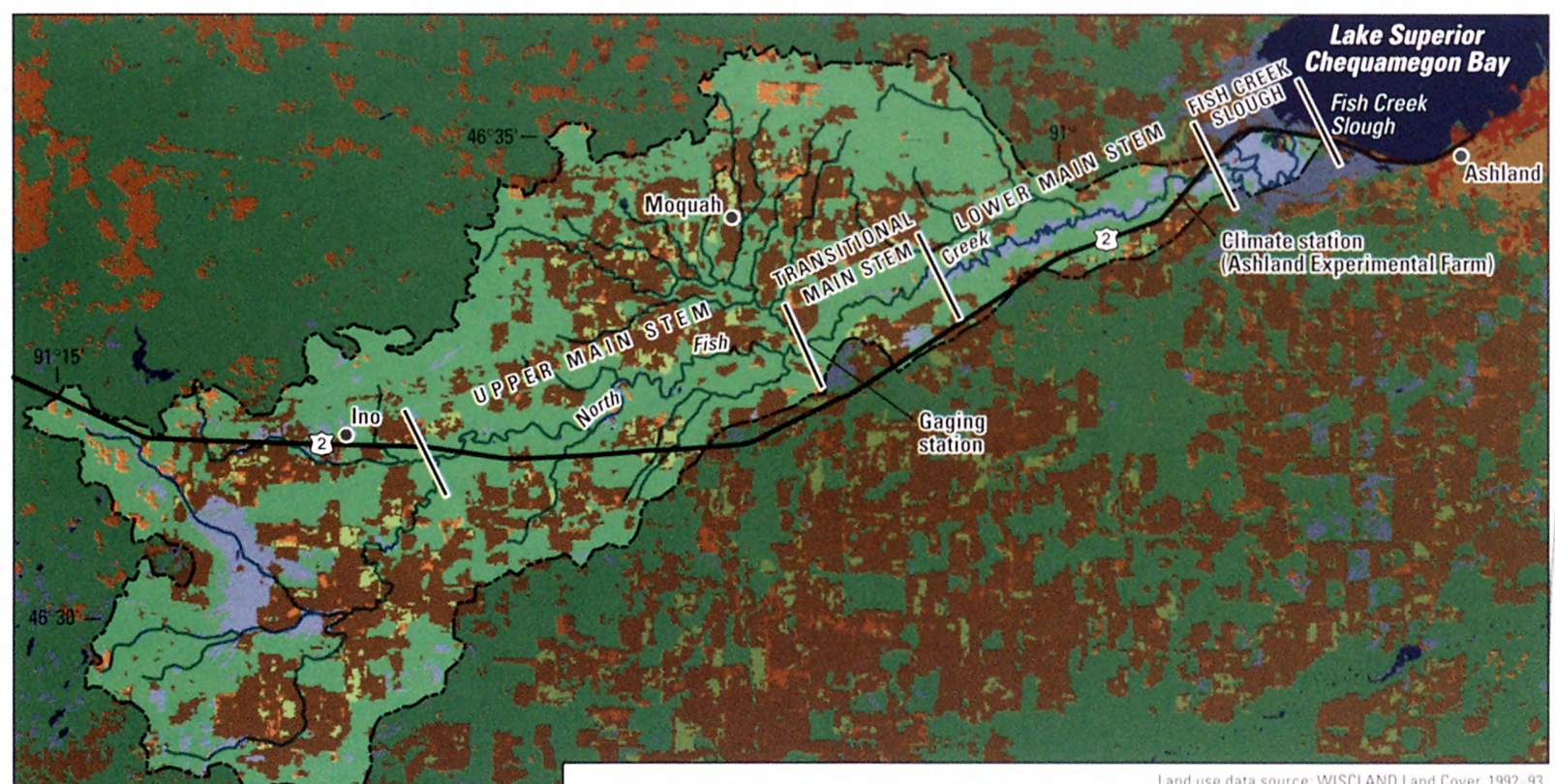

Figure 1. Location and major land cover characteristics of North Fish Creek.

EXPLANATION

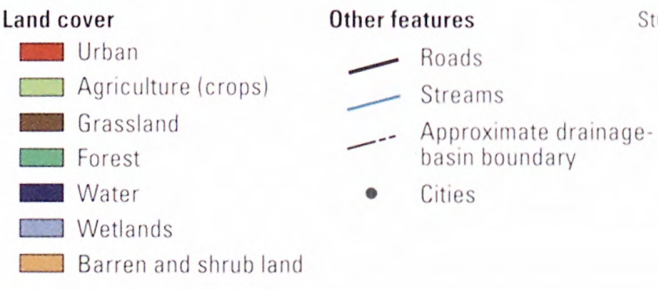

WISCONSIN

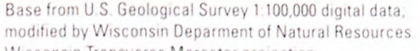

4 MILES

4 KILOMETERS

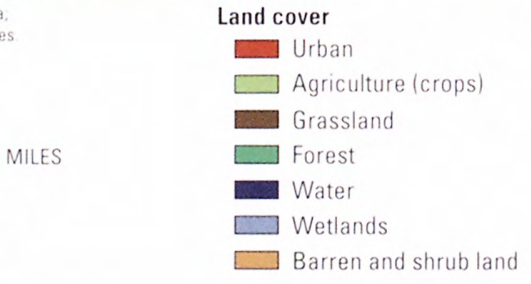

ther features

- Roads

-. Approximate drainage.

- Cities 


\section{INTRODUCTION}

North Fish Creek, a 122-kilometer ${ }^{2}$ Wisconsin tributary to Chequamegon Bay, Lake Superior (fig. 1), is an important recreational fishery that is potentially limited by the loss of aquatic habitat caused by accelerated erosion and sedimentation (B. Swanson, Wisconsin Department of Natural Resources, written commun., 1994). Although most of the land in the drainage basin is forested, large floods in the past have contributed to severe erosion problems (Johannes and others, 1970). Potential accelerated sedimentation rates near the mouth of North Fish Creek also may be affecting fish and waterfowl habitats in Fish Creek Slough.

Flooding and sedimentation are common problems for many southern Lake Superior tributaries, and Wisconsin shorelines and streams are known to be major contributors of sediment to Lake Superior (Robertson, 1996; Natural Resources Conservation Service and U.S. Forest Service, 1998). North Fish Creek was selected as a typical example of such a tributary as the focus of a cooperative study between the U.S. Geological Survey and the Wisconsin Department of Natural Resources to determine how flooding and sedimentation characteristics for similar Lake Superior tributaries may have changed in response to changes in land cover after European settlement of the region in the 1870 's. Rates of and responses to human-influenced runoff and erosion were compared to those expected from natural changes in climatic conditions and relative water level of Lake Superior.

North Fish Creek is naturally susceptible to large floods and erosion problems because of its geologic setting. Surficial deposits in its basin consist mainly of red clay, with some areas of sandy deposits along the northern and southwestern edges of the basin. The sandy deposits also are present beneath the red clay and are exposed in many of the 25-meter-high bluffs along the stream. The bluffs are highly susceptible to erosion where they are undercut by flowing water. Soils developed in the red clay have a very low infiltration rate- 0.25 centimeters per hour $(\mathrm{cm} / \mathrm{hr})$ (Krug and others, 1992). The rate of precipitation and (or) snowmelt, however, commonly exceeds 0.25 $\mathrm{cm} / \mathrm{hr}$; therefore. North Fish Creek naturally has the potential to be a "flashy stream" with frequent, large floods. In contrast, soils developed in the sandy deposits have an infiltration rate of $19 \mathrm{~cm} / \mathrm{hr}$ and, hence, they are associated with minimal surface runoff (Krug and others, 1992). Ground-water recharge in the sandy areas supplies abundant springs that discharge to North Fish Creek. The flow from these springs accounts for the exceptionally high base flow in the creek.
This report presents the results from the above-mentioned study of the ways in which historical land-cover changes have affected flooding and sedimentation in North Fish Creek, and illustrates how geomorphic field techniques and hydrologic modeling were used to determine changes in North Fish Creek after European settlement. The report describes

- major human and natural influences on flooding and sedimentation,

- the major source of sediment to the stream,

- changes in channel characteristics and flood size after European settlement.

- comparisons between pre- and post-settlement erosion and sedimentation rates and overall channel adjustments,

- a post-settlement sediment budget, and

- implications of study results on land and water management.

\section{Relevant Fluvial Geomorphology Concepts}

Simply defined, fluvial geomorphology is the study of landforms and processes related to streams and flowing water. It is the study of why specific landforms are present, what surficial processes create them, and how landforms develop and change over many years. Geomorphic studies are typically based on field observations supported by empirical equations and laboratory analysis. The geomorphic terminology and concepts used in this report are described in the following paragraphs.

A stream channel is just one of many landforms created by flowing water (fig. 2). Streambanks form the steep or sloping ground that borders a channel and confines the water to the channel when the water level, or flow, is normal. The flood plain is generally a flat to gently sloping depositional surface adjacent to the channel that is occupied by the modern stream. The elevation of this active flood plain is considered here to be the same as bankfull stage. The bankfull stage is the point at which water just begins to overflow the channel and spill out onto the flood plain. Field indicators used for determining bankfull stage include any breaks in the slope along streambanks, and the average maximum elevation of sand deposition on point bars (Wolman and Leopold, 1957). In general, bankfull flows are expected to occur on average every 1 to 2 years (Leopold and others, 1964), although considerable variability in the recurrence interval has been found among streams (Williams, 1978). A terrace is an abandoned flood plain that formed when the stream flowed at a higher elevation than at present. Terraces are no longer related to the modern flow regime of the stream.

The course of a stream sometimes changes location during large floods when water flows over the flood plain. Channels may also be

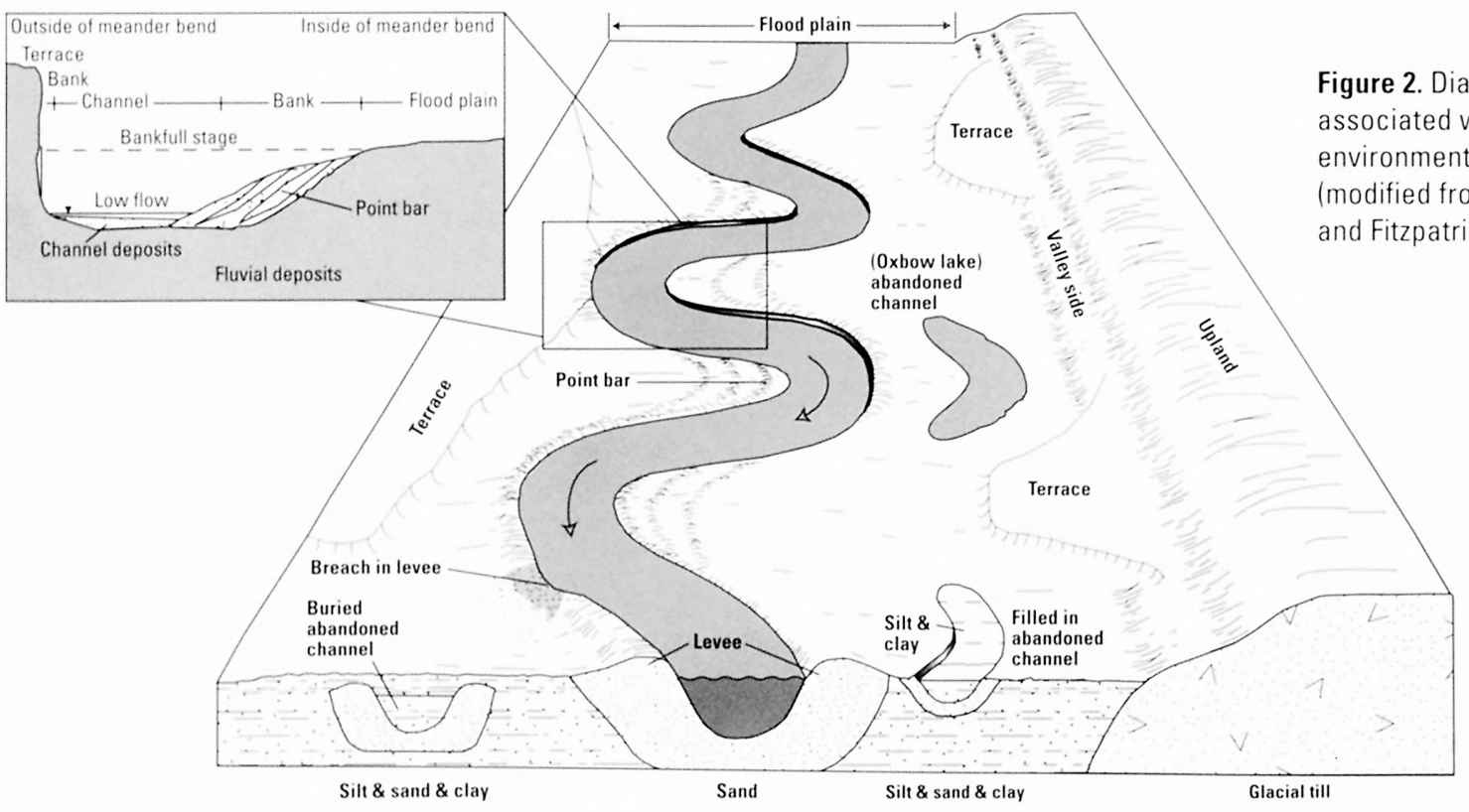




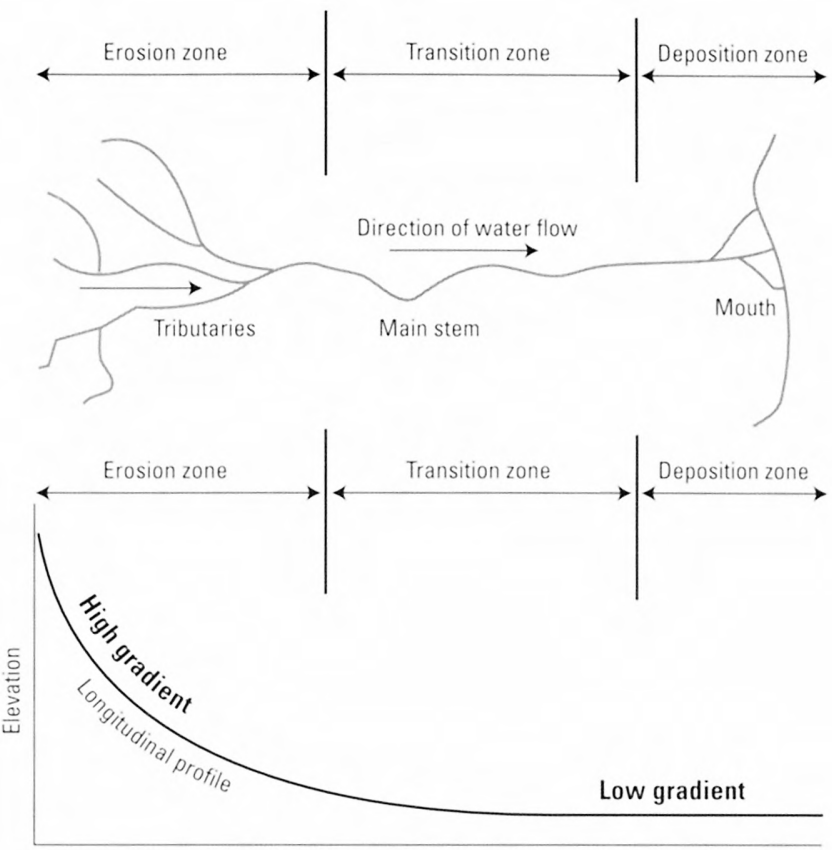

Distance upstream from mouth

Figure 3. Overhead view and longitudinal profile of geomorphic zones within a stream network (modified from Schumm, 1977).

abandoned when curves in the course of the stream, or meanders. migrate laterally and eventually intersect. The characteristics of these abandoned channels are preserved in flood-plain deposits. Some abandoned channels may be filled with water (oxbow lakes), whereas other channels may become buried by sediment deposited on the flood plain during floods (fig. 2).

Stream networks commonly consist of an erosion zone (where sediment and runoff are generated), a transfer or transitional zone (where sediment and water are transferred through with no gain or loss of material), and a deposition zone (where sediment from upstream erosion is dropped out of transport) (Schumm, 1977) (fig. 3). The longitudinal profile of a stream illustrates how the gradient, or slope, of a stream changes from relatively high in the erosion zone to relatively low in the depositional zone near the mouth.

Streams are dynamic features that adjust their physical characteristics to prevailing climate, geology, topography, vegetation, and base level (the level, or elevation, at which a stream enters a major water body). A change in any of these conditions may cause a stream to alter the dimensions, elevation, gradient, and location of its channel. Channel adjustments can occur over periods as brief as individual storms to as long as thousands of years. The type of channel adjustment resulting from an environmental disturbance or change depends on the location of the channel within the stream network.

The ability or power of a stream to erode and transport sediment is increased if the amount and intensity of runoff resulting from rainfall or snowmelt are increased (Leopold and Maddock, 1953). If the amount and intensity of runoff are increased, channels in an erosion zone of a stream network may become steeper and have unstable, eroding streambanks and channel beds, whereas channels and flood plains in the depositional zone of a stream network will become filled with sediment as the additional sediment from upstream is deposited.

The onset of channel-bed erosion creates a strong positive feedback that maintains or even intensifies the erosion. Even large streamflows may be confined within increasingly entrenched channels with increasing water-conveying capacity, and streamwater will not spill out into the old flood plain as frequently as in the past. This increased capacity results in little sediment being deposited on the old flood plain in the erosion zone. Meanwhile, the erosive power of the stream channel is increased, the channel bed continues to erode, and more water and sediment are transported downstream. Over time, streambank erosion may continue as the stream begins to build a new flood plain through meandering. Channels in the transition zone between the erosional and depositional zones will be the most sensitive and will respond the most quickly to changes in runoff and sediment characteristics.

\section{Importance of Geomorphic Studies for Land and Water Management}

Measuring and modeling floods and instantaneous sediment movement and transport are useful for short time periods, but such methods are not adequate for representing changes in physical characteristics of channels and flood plains over decades, centuries, or millennia. Alternatively, geomorphic methods provide insight into the long-term history of channel changes and place these changes in the context of related flood-plain processes and upstream/downstream effects. Geomorphic field studies are particularly useful for putting human-caused changes in land cover into perspective with climatic and other natural changes. Thus, geomorphic studies are useful for determining the goals and for assessing the effectiveness of water-resources management, protection, and restoration. Comparison of modern changes in flooding and sedimentation to past natural environmental changes can, in some instances. provide useful glimpses of future stream changes that might result from additional land-cover alterations.
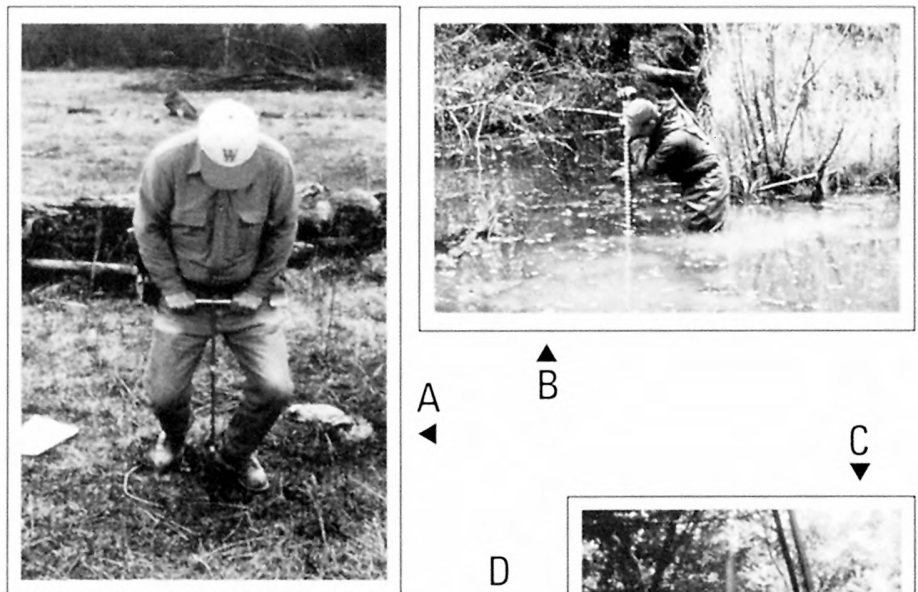

$\hat{B}$
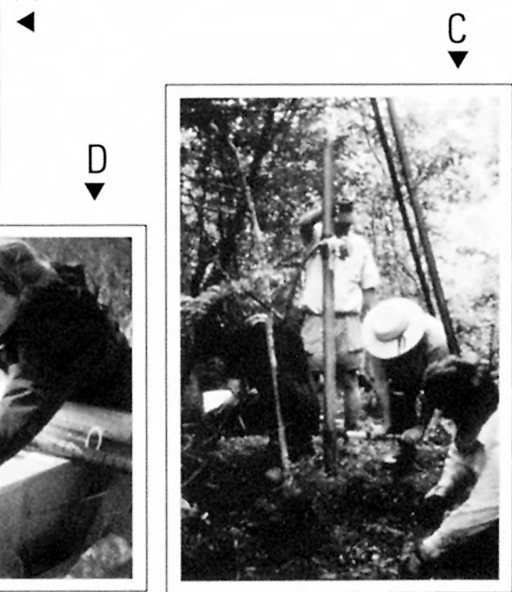

Figure 4. Coring techniques used for collecting sediment samples from the flood plain and channels of North Fish Creek.

A) soil probe,

B) piston corer,

C) vibrating corer,

D) examination of a piston core from Fish Creek Slough. 


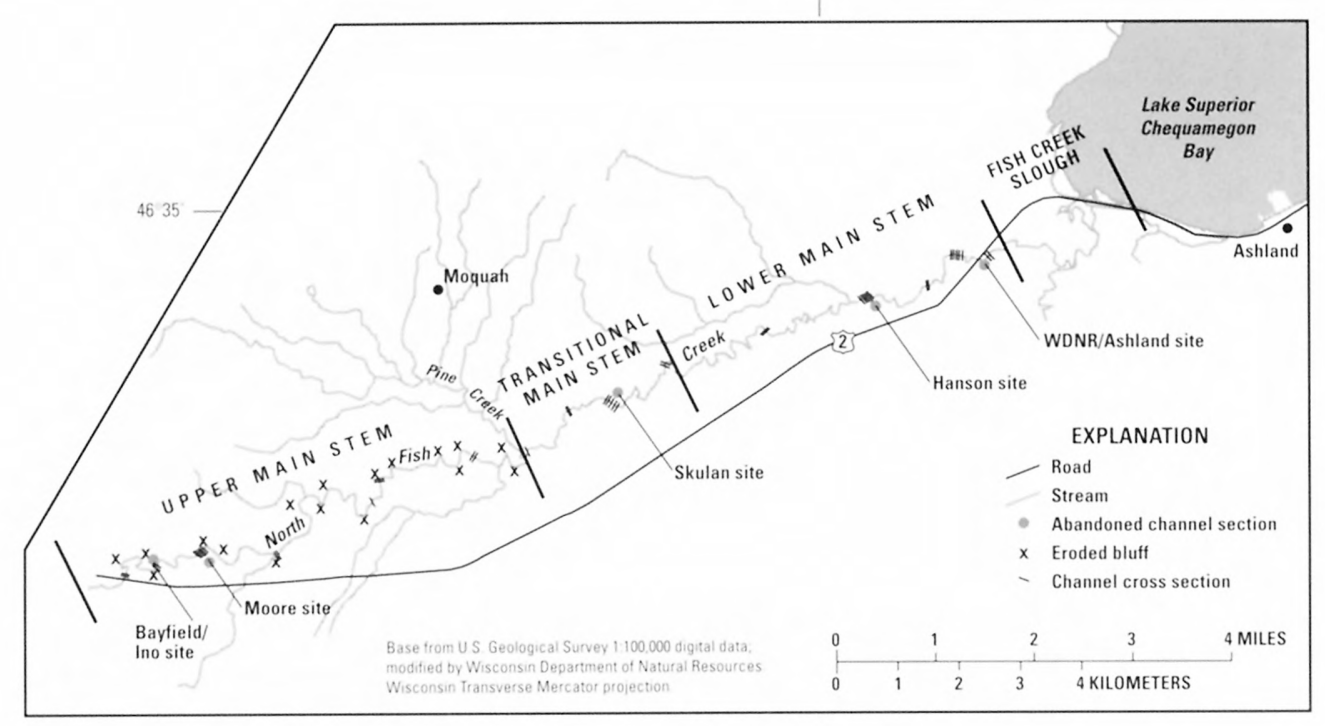

Figure 5. Locations of channel cross-sections and eroding bluffs along North Fish Creek. For this study, the main stem of North Fish Creek was divided into 3 zones primarily based on changes in gradient. The upper main stem has a high gradient and the lower main stem has a low gradient. The gradient changes from high to low gradient in the transitional main stem.

\section{Methods Used in the North Fish Creek Study}

Historical changes in flooding and sedimentation for North Fish Creek were reconstructed from field and laboratory analyses of sediment cores extracted at various field sites. Hydrologic and sedimenttransport modeling and historical documents were used to supplement field data. A detailed description of the methodology used in this study can be found in Fitzpatrick (1998). Relative degree of soil development. radiocarbon-age dating. and landscape position were used to determine pre- and post-settlement rates of erosion and sedimentation. About 200 sediment cores were collected from flood-plain, channel, and mouth areas of North Fish Creek in 1994 and 1995 (fig. 4). Streambank and bluff exposures also were examined to reconstruct historical and presettlement erosion and sedimentation rates. Selected sediment samples from cores and exposures were analyzed for sediment particle size and organic carbon content. Samples of wood and organic material also were collected for radiocarbon age determinations. For calculating sedimentation rates and ages of abandoned channels, calendar-calibrated ranges were calculated from conventional radiocarbon ages using a calibration procedure based on tree-ring data (Stuiver and Reimer, 1993). The calendar-calibrated radiocarbon age (in A.D. or B.C. years in this report) is given as a range that includes a possible statistical error of 2 standard deviations (95-percent probability).

The ages of five abandoned channels (fig. 5) along the upper. transitional, and lower main stem were determined, and the size. elevation, gradient, and sediment characteristics of the abandoned channels were used to estimate bankfull flows and erosion and sedimentation rates. HEC-2 flood-profile software was used to estimate bank full flows in the modern and abandoned channels (U.S. Army Corps of Engineers, 1991). Estimated flow volumes also were determined for full-channel-capacity flows-defined here as the cross-section capacity

extending to the level of the now relict historical flood plain in areas of channel downcutting and (or) active bank erosion.

The HEC-1 rainfall/runoff model (U.S. Army Corps of Engineers. 1990) was used to estimate the variability in flood peaks for various types of land cover in North Fish Creek. Flood peaks were modeled for a historical summer storm expected to occur on average approximately every 2 years (Hershfield, 1961). The modeled floods were integrated with sediment-transport relations derived from streamflow and sediment data collected at a gaging station on North Fish Creek near Moquah (fig. 1) (Rose and Graczyk. 1996: Fitzpatrick, 1998). The hydrologic/sediment-transport model was calibrated with gaging-station data. Three land-cover scenarios were modeled: complete forest (representing pre-settlement conditions), peak agriculture in the mid$1920^{\circ}$ s to mid-1930's (as represented by land-use statistics reported in the Bayfield County 1928 Land Economic Inventory), and current conditions (from 1992-93 WISCLAND satellite imagery). Seven small detention basins were added to the watershed model to determine the extent to which they would sufficiently reduce flood peaks, which, in turn, might decrease erosion.

The 1855 Government Land Office (GLO) survey notes were used to compare modern and pre-settlement channel-width and streambedsediment characteristics. In addition to containing detailed descriptions of the pre-settlement vegetation, the surveys also included locations of streams at section lines, the width and direction of the stream, characteristics of streambed sediment, water clarity, and flow. Other historical documents, such as aerial photographs, bridge-construction records, and newspaper articles, also were used to support field and laboratory data. (Newspaper articles contained information about recreational fishing, logging, and flooding on North Fish Creek.)

Figure 6. Photographs of North Fish Creek at railroad crossing, Ashland Junction, Wis., sec. 2/3, T. 47 N., R. 5 W., Ashland Junction, Wis.

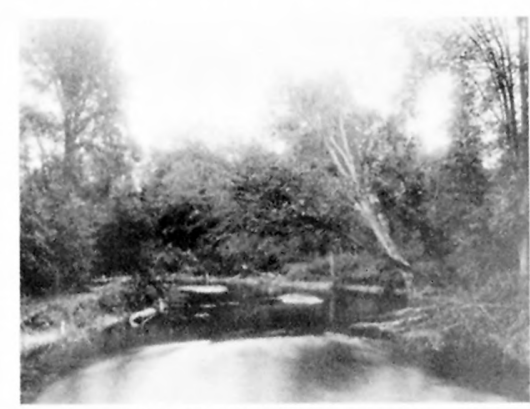

A) circa 1885-88 (J.M. Turner and Co., 1889), reproduction courtesy of State Historical Society of Wisconsin, negative no. WH:(X3)51439,

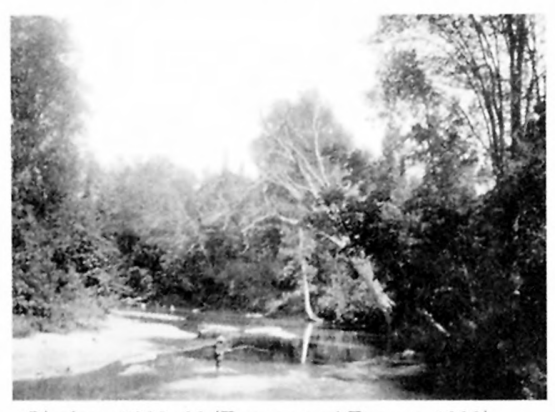

B) circa 1888-98 (Turner and Turner, 1898),

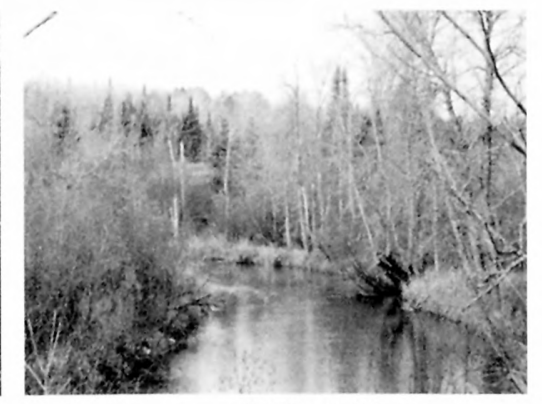

C) 1997 (courtesy of D. Pratt, Wisconsin Department of Natural Resources, Superior, Wis.) 


\section{MAJOR INFLUENCES ON FLOODING AND SEDIMENTATION}

Three major factors influence the flooding and sedimentation characteristics of North Fish Creek-land cover, climate, and base level. Clearing and burning of forests after European settlement of the region constituted an extreme disturbance of land cover. Minor climate and base-level changes also have occurred since European settlement.

\section{Changes in Land Cover}

The removal of forest cover may result in an increase in the size and peaks of floods by increasing surface runoff (Verry. 1987). If forest vegetation is allowed to return, recovery to pre-logging hydrologic conditions may take from only a few years to several decades (Reinhart and others, 1963). However, in areas where the natural vegetation is permanently converted to agriculture, substantial long-term changes in flooding and sedimentation occur (Knox, 1977; Jacobson and Primm. 1997).

Before European settlement, the natural vegetation of the North Fish Creek Basin consisted mainly of balsam fir/white spruce forest (Finley. 1976). Most of the logging and burning of old-growth forests in the basin took place from 1882 to 1889; more than 47 million board feet of logs were floated down North Fish Creek to sawmills on the shoreline of Chequamegon Bay (D. Pratt. Wisconsin Department of Natural Resources, written commun., 1996). The significant short-term damage to streambanks caused by log drives can be seen in a series of photographs of North Fish Creek (fig. 6). Approximately 10 years after the log drives had ended, the streambanks started to stabilize (fig. 6B). A photograph of the same location in 1997 (fig. 6C) shows that the streambanks are much more vegetated and the channel more narrow under modern land cover than they were during the log drives.

After the decline in logging. major agricultural development in the region occurred from 1895 to 1920 (Mahaffey and Bassuk. 1978). Agricultural activity peaked in the mid-1920's to mid-1930 s, with much of the upland areas consisting of cropland (forage crops and some corn) and pasture for dairy cattle (fig. 7). Since the peak agricultural activity, the relative amount of agricultural land (cropland and pasture/ grassland) and forest has changed little: however, the amount of cropland was about 22 percent in 1928 compared to 3 percent in 1992 93 (fig. 7). In 1992, nearly one-third of the basin (31 percent) was classified as grassland, which is a combination of grazed or abandoned pastures for dairy or beef cattle (Lillesand and others, 1998). The average age of forests in the basin was probably less in 1928 than in 1992-93, based on the small size of trees recorded in the 1928 Land Economic Inventory (Wisconsin Department of Agriculture and Wisconsin Geological and Natural History Survey, 1928).

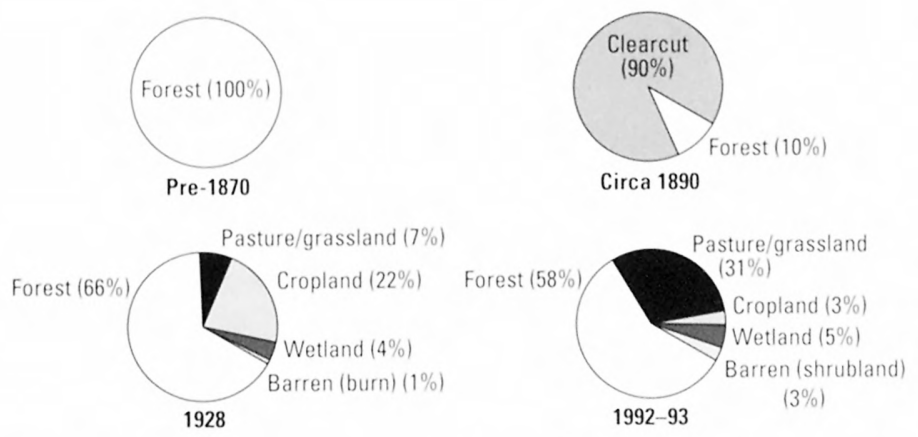

Figure 7. Land-use history in the North Fish Creek Basin (pre-1870, 1855 government land office surveys; circa 1890, historical accounts, and newspaper articles; 1928, Land Economic Inventory; 1992-93, WISCLAND satellite data)

\section{Changes in Climate}

In addition to land cover, climate also affects the frequency and magnitude of floods and sediment loads by affecting the intensity, frequency, and magnitude of rainfall and snowmelt (Knox, 1983; 1984). Depending on the position of a stream within a stream network (fig. 3), the response of a stream to climatic change can be sedimentation. erosion, meandering variability, or changes in the dimensions of channels. Infrequent, large floods can trigger substantial geomorphic change (Baker and Costa, 1987). Such floods, although rare, can cause the formation of stream terraces and new flood plains and can transport coarse sediment. Small, frequent floods are important in rebuilding channel shape after large floods (Wolman and Leopold, 1957). Large storms, when followed by frequent storms of even moderate magnitude, have been observed to be particularly destructive to channel stability (Schumm and Lichty, 1963).

No long-term streamflow records are available for North Fish Creek: therefore, its flood history was reconstructed from the precipitation record at the Ashland Experimental Farm (fig. 1) and from local newspaper accounts. Because large floods can destabilize a river system, rainfalls greater than $7.6 \mathrm{~cm}$ (3 inches) were identified for the period of record (1900 to 1997) at the precipitation station (fig. 8). These rainfalls are greater than the 2-year, 24-hour rainfall for the area, which is approximately $6.4 \mathrm{~cm}$ (Hershfield. 1961). The precipitation record shows that the temporal distribution of large storms from 1900 to 1997 was episodic. Multiple rainfalls greater than $7.6 \mathrm{~cm}$ occurred in some years, whereas no rainfalls exceeded $7.6 \mathrm{~cm}$ during several 2- to 5 -year periods (fig. 8). The most obvious 5-year periods without major rainfalls were 1932-37, 1965-70, and 1986-91. In contrast, frequent large rains between 1949 and 1954 followed the exceptionally large rains of August 1941 and June 1946.

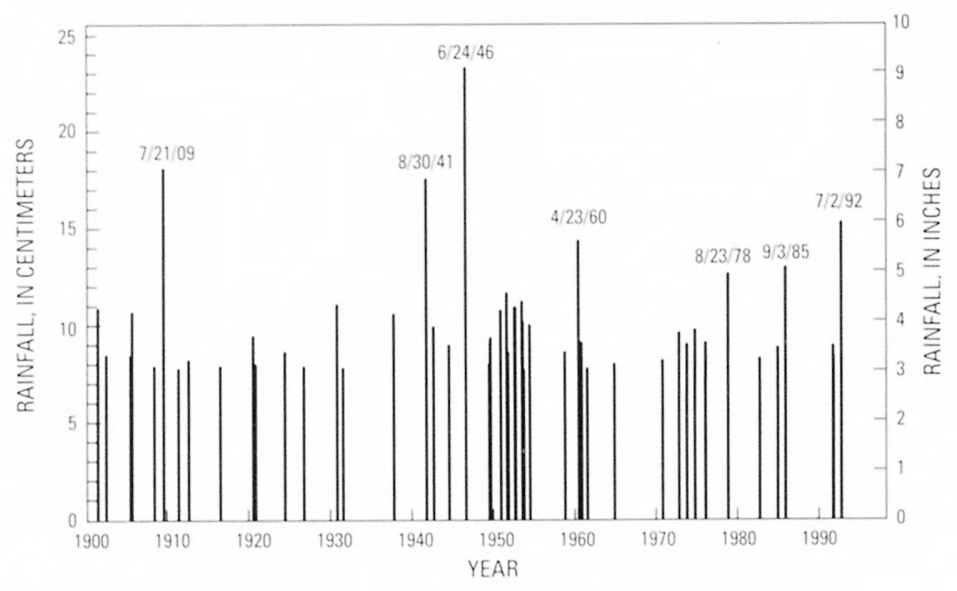

Figure 8. Rainfalls greater than 7.6 centimeters ( 3 inches), Ashland Experimental Farm, Wis., 1900-97.

The 1946 storm was by far the largest on record. Total precipitation over the 2-day period was greater than $23 \mathrm{~cm}$. For comparison, the estimated 100-year, 24-hour rainfall for the Ashland area is $11.4 \mathrm{~cm}$ (Hershfield, 1961). Several roads, buildings, and rail bridges were washed out along the tributaries and main stem of North Fish Creek and at the mouth of Fish Creek.

\section{Changes in Base Level}

Rising lake levels typically cause tributary mouths to fill with sediment, whereas falling levels cause channel erosion at tributary mouths (Larsen, 1985). For North Fish Creek, a change in base level was caused mainly by changing levels of Lake Superior over the last several thousand years. The overall level of Lake Superior since 1860 at the 


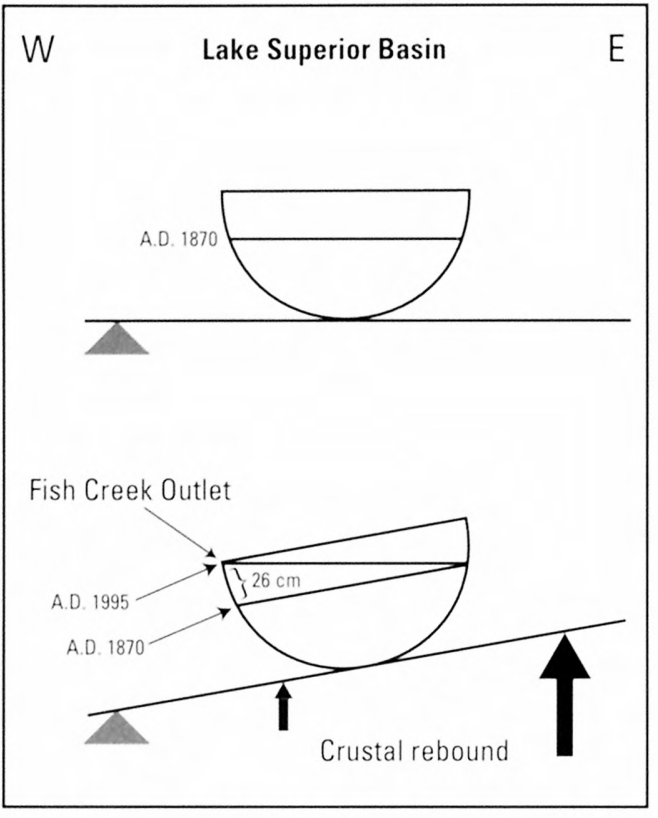

Figure 9. Effects of differential crustal rebound on shoreline elevations for Lake Superior.
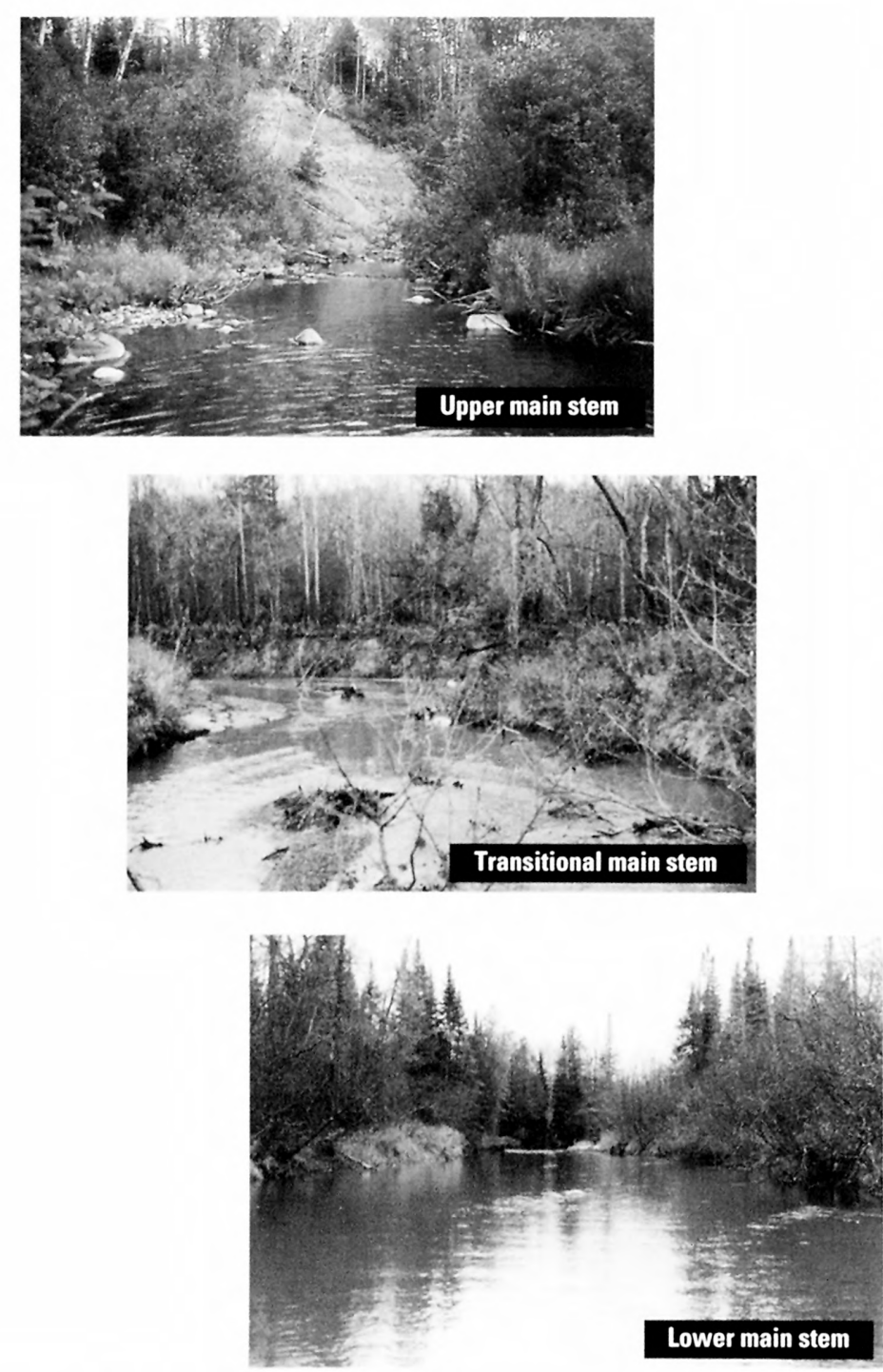

Figure 10. Photographs of the upper, transitional, and lower main stem of North Fish Creek.
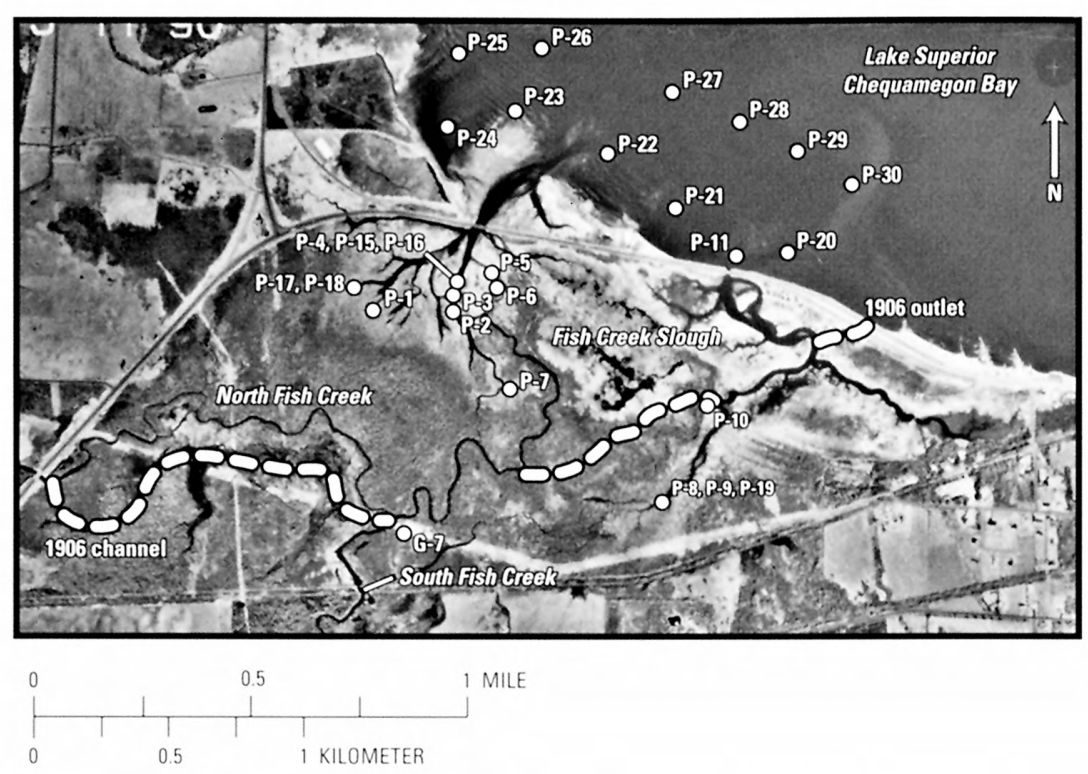

Figure 11. 1990 aerial photograph of Fish Creek Slough with locations of cores collected in 1995. The 1906 channel location was interpreted from historical maps.

control gage near its outlet has been fairly constant at about 183 meters $(\mathrm{m})$ because of human stabilization (International Joint Commission. 1976; U.S. Department of Commerce, 1973): however, the elevation of the water surface of the Chequamegon Bay area has increased by about $26 \mathrm{~cm}$ relative to the land surface since the 1870 's (fig. 9). This increase is caused by regional differences in crustal rebound after glacial ice melted from the region about 10.000 to 11,000 years ago (Larsen, 1994). The land on the eastern half of Lake Superior, which was more depressed by glacial ice, is rising at a faster rate than land on the western half (fig. 9).

\section{POST-SETTLEMENT CHANGES IN FLOODING AND SEDIMENTATION}

In this section, post-settlement flooding and sedimentation changes in North Fish Creek are described for three reaches along the main stem and Fish Creek Slough (fig. 5). Example photographs illustrate the modern differences in channel characteristics along the main stem (fig. 10). The upper main stem is characterized by a cobble/boulder and sand channel bed, eroding bluffs, and a high gradient $(0.0159 \mathrm{~m} / \mathrm{m})$. In the transitional main stem. a shift from high to low gradient is reflected by a progressive downstream change from cobble/boulder and sand channel bed to a gravel and sand channel bed. The lower main stem is characterized by a predominantly sandy channel bed, low streambanks. and a relatively low gradient $(0.00127 \mathrm{~m} / \mathrm{m})$. The main channel of Fish Creek through Fish Creek Slough (fig. 11 ) also contains a sandy channel bed.

\section{Source of Sediment in North Fish Creek}

A study of sediment loadings in North Fish Creek at the gaging station (fig. 1) indicated that upland erosion is not a major source of sediment to the creek (Rose and Graczyk, 1996). A comparison of eroding bluff locations (fig. 5) from 1938 and 1990 aerial photographs indicate that bluff erosion along the upper main stem can account for most of the sediment load observed at the gaging station. On the basis of the aerial photograph comparisons, bluffs retreated at an average rate of $25 \mathrm{~m}$ over 52 years, or about $0.5 \mathrm{~m} / \mathrm{yr}$. The combined amount of sediment lost from all the bluffs over this 52 -year period is about 9,800 $\mathrm{m}^{3} / \mathrm{yr}$, or 14,100 tonnes/yr. Photographs of a large bluff along the upper main stem of North Fish Creek in 1994 and again in 1996 (fig. 12) show 
Figure 12. Photographs of eroding bluff along North Fish Creek, upper main stem, 1994 and 1996.
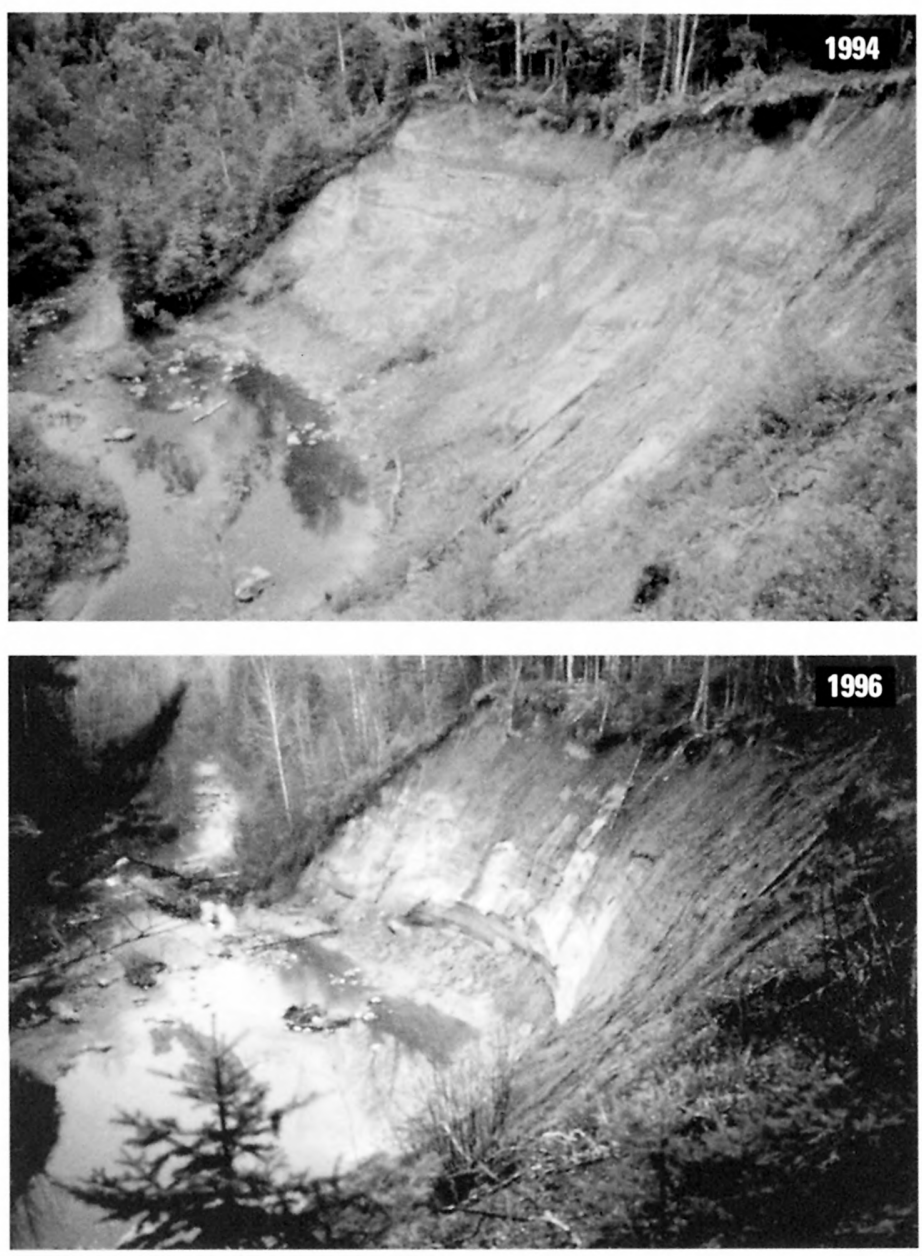

observable bluff retreat and substantial change in the channel location over only a 2-year period. The eroding bluffs along North Fish Creek expose varied sedimentary beds, ranging from clayey tills and boulders deposited in former glacial ice-contact settings to sand and silt deposited by former glacial-meltwater runoff and ponding. On the whole, the eroding bluffs are sources for substantial amounts of sand. They average about 49 percent sand, with individual beds ranging from nearly all silt to nearly all sand. Rose and Graczyk (1996) estimated an average annual total sediment load at the gaging station of approximately 13,800 tonnes/yr in 1990-91, and 60 percent of that sediment load was sand.

\section{Changes in Channel Characteristics and Small, Frequent Floods}

In general, the texture of streambed sediment in North Fish Creek has not changed since the 1855 GLO survey. For example, the lower main stem had a sandy bed in 1855 as well as in 1995. One exception was at the Hanson site (fig. 5), where the 1855 GLO survey recorded a rocky streambed sediment. No evidence of rocky streambed sediment was found, however, in cores from the modern channel, in two nearby abandoned channels, or in the flood plain.

Post-settlement changes in channel width were dependent on the location along the main stem. Comparisons of 1995 and 1855 channel widths indicate that the channel narrowed somewhat in the upper main stem and widened in the lower main stem (fig. 13). The change from narrowing to widening corresponds with a shift from a high gradient to a relatively low gradient channel from upstream to downstream.

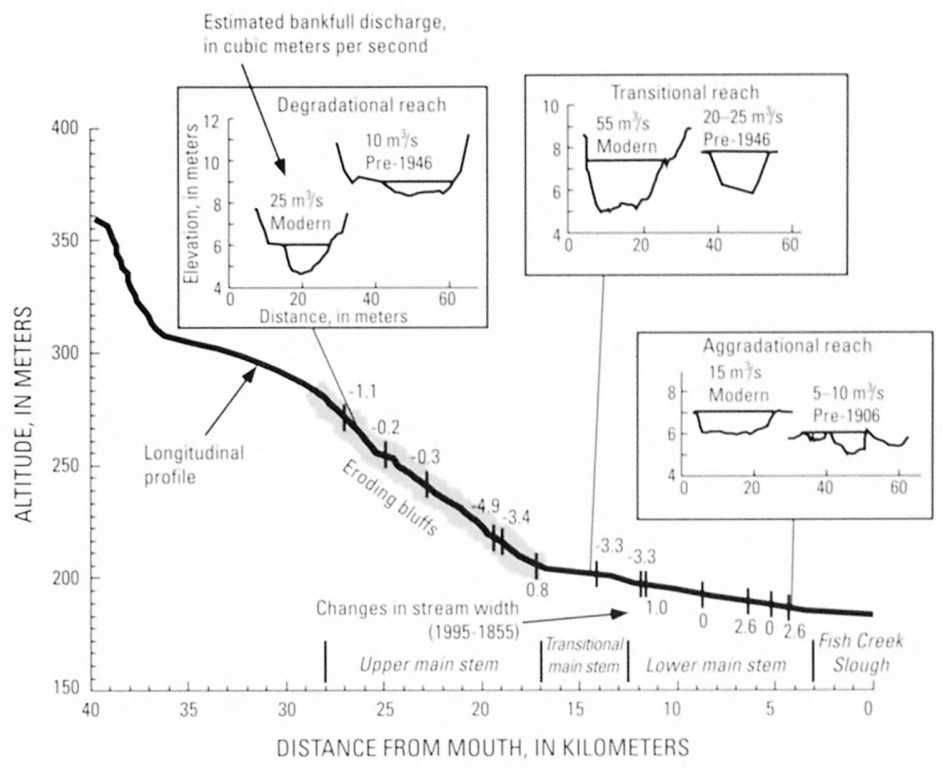

Figure 13. Longitudinal profile of North Fish Creek with changes in channel width, 1855-1990 and estimates of bankfull flow capacity. Stream-width changes calculated from 1855 Government Land Office surveys and from cross-section surveys done as a part of this study in 1995.

Geomorphic evidence indicates that the modern bankfull flow along the upper and transitional main stem is as much as 2.5 times greater than the pre-1946 bankfull flow (fig. 13). The pre-1946 channel cross sections shown in figure 13 are from channels abandoned during the 1946 flood. Bankfull flows and the sizes of the modern and pre-1906 channels appear to be about the same in the lower main stem.

Rainfall/runoff model simulation results for the gaging station near Moquah (fig. 1) indicate that under peak agricultural land use in the basin (about 1928), flood peaks expected to occur on average every 2 years were about 3 times greater than under pre-settlement forest cover. Flood peaks of this recurrence interval under modern land cover are about twice as large as their pre-settlement counterparts (fig. 14). An actual flood peak under complete forested conditions probably was even smaller than the modeled flood because the model did not account for potential decreases in the thickness of an organic detritus layer on the forest floor after logging and burning.

\section{Changes in Erosion and Sedimentation Rates}

Geomorphic evidence and model simulation results indicate that post-settlement changes in land cover in the North Fish Creek Basin affected erosion and sedimentation rates and sediment loads. Figure 14 shows the storm hydrograph for a 2-year flood under 4 modeled conditions and under current, observed conditions. During peak agricultural activity in the 1930 's, sediment loads were 2.5 times greater than under modern land cover and may have been 5 times greater than under pre-settlement forest cover. Field evidence indicates up to a ninefold increase in post-settlement erosion and sedimentation rates over natural pre-settlement rates. These rates are systematically dependent on location along the main stem.

For the upper main stem of North Fish Creek. interpretations from cores, eroding cut banks, valley transects, abandoned channels, and historical bridge data indicate that the channel bed eroded a minimum of 1 to $3.5 \mathrm{~m}$ along the upper main stem since the $1870^{\circ} \mathrm{s}$. An example valley cross section from the Moore site (figs. 5 and 15) illustrates how the modern channel is entrenched compared to a channel abandoned during the 1946 flood. The valley cross section illustrates the absence of a modern flood plain, which is typical for streams that are downcutting 


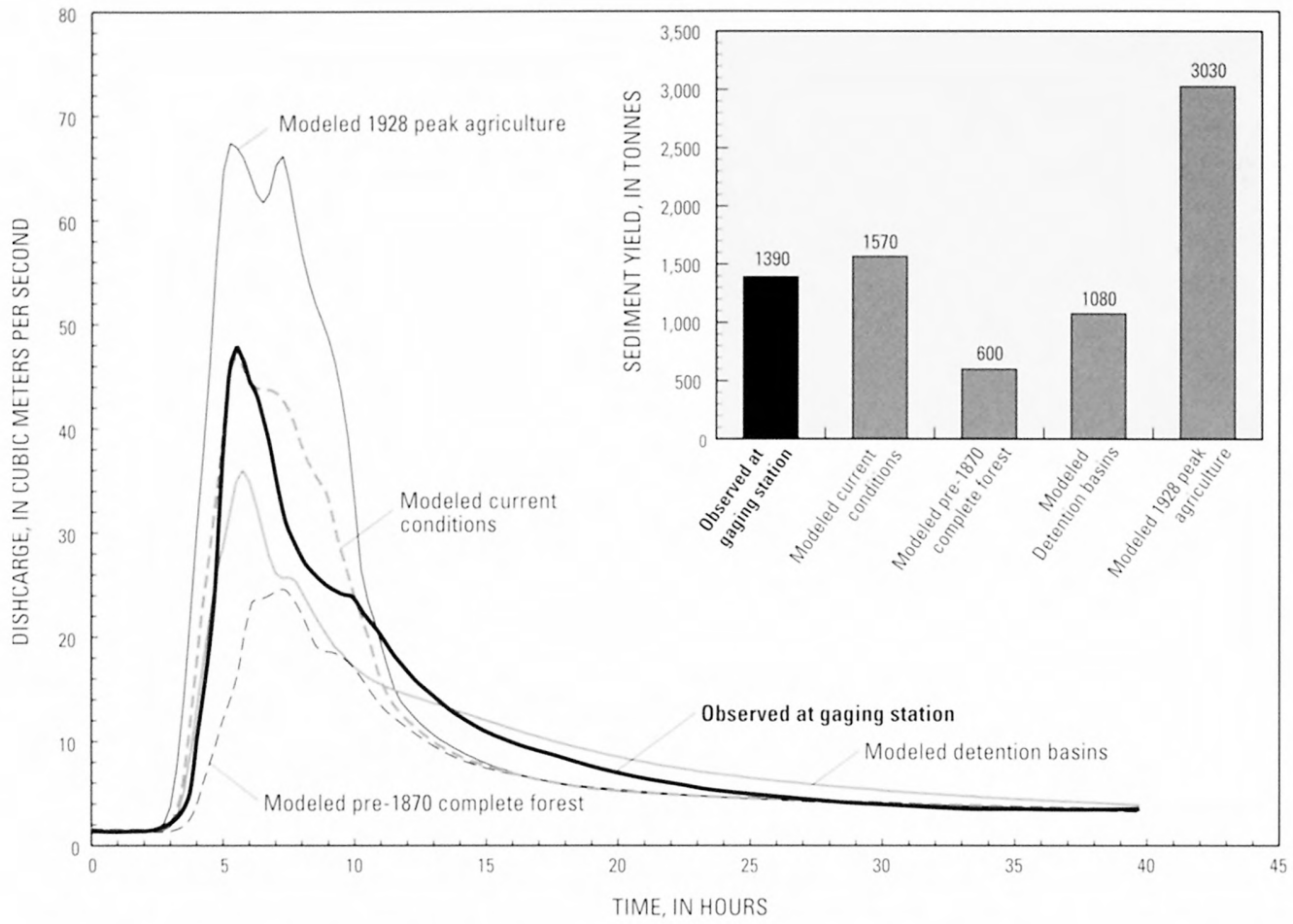

Figure 14. Storm hydrographs and sediment loads for North Fish Creek near Moquah, Wis., for a historical storm on September 3, 1991, under four land-cover conditions.

rapidly. This entrenchment makes the modern channel very efficient at transporting water and sediment. Most floods are now confined within the entrenched channel, and the potential for erosion is not dissipated as it was in the past when even small floods spilled out onto a more extensive flood plain. The presence of at least five terraces and the deposits beneath them at the Moore site indicate that the upper main stem has been subject to many episodes of erosion over the last 10.000 years.

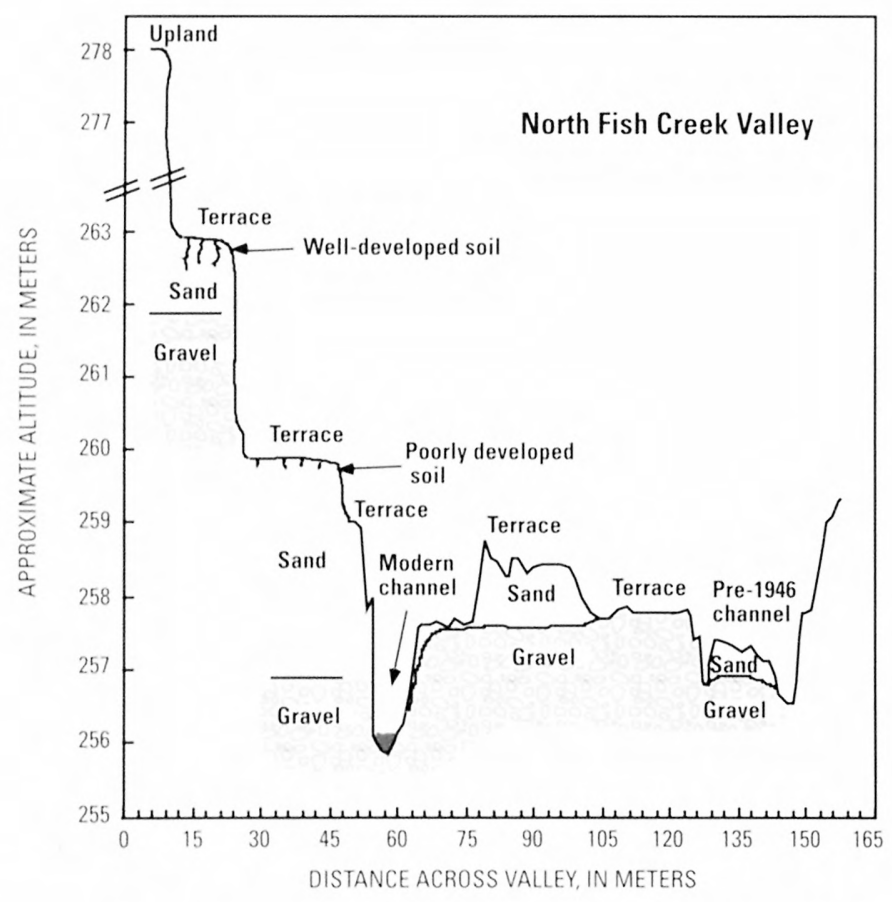

Figure 15. Valley cross section of North Fish Creek at the Moore site, upper main stem.
Field evidence indicates that postsettlement flood-plain sedimentation rates have been highest along the transitional main stem. Field evidence also indicates post-settlement channel erosion along the transitional main stem. Approximately 0.5 to $2 \mathrm{~m}$ of post-settlement fine sand covers the pre-settlement flood-plain surface. An example of core and eroding cutbank data from a partial valley cross section from the Skulan site (figs. 5 and 16) illustrates the relations between pre-and post-settlement flood-plain surfaces, terraces, and channel-bedelevations. A wood sample from a buried soil $2 \mathrm{~m}$ below the top of an eroding terrace exposure (fig. 16) has a radiocarbon age of A.D. $1545 \pm 405$, supporting the identification of this buried soil as the pre-settlement flood-plain soil (pre-A.D. 1870). A radiocarbon age of A.D. $1525 \pm 115$ for wood buried below the pre-settlement soil in this same terrace exposure indicates that. at this location, the post-settlement sedimentation rate of $1.6 \mathrm{~cm} / \mathrm{yr}$ is 9 times greater than the pre-settlement sedimentation rate of $0.17 \mathrm{~cm} / \mathrm{yr}$. Coarse sand layers in the uppermost part of the Skulan terrace cut. in addition to accumulation of organic material and weak soil development, indicate that only extremely large floods overtop this terrace surface under modern conditions.

The channel bed along the transitional main stem also eroded approximately $1 \mathrm{~m}$ since 1946, as evidenced by the elevation difference between beds of the modern channel and a channel abandoned during the 1946 flood (fig. 16). The combination of channel-bed erosion and flood-plain sedimentation resulted in an entrenched channel along the transitional main stem. This channel, similar to the upper main stem channel, is efficient at rapidly moving sediment and water downstream. The transition from high to low gradient makes the transitional main stem particularly sensitive to changes in runoff and sediment contributions from upstream. The gravel beds along this reach provide spawning habitat for several Lake Superior fish species. These beds are highly susceptible to scour and (or) burying by transported sand.

At the same locality. the bed of a buried abandoned channel below a terrace surface has a calibrated radiocarbon age of $1670 \pm 20$ B.C. (fig. 16). The bed of this approximately 3.700 -year-old channel is at an elevation similar to that of the modern channel bed. The elevation of the pre-1946 channel bed $1 \mathrm{~m}$ above the dated wood indicates that some sedimentation in this reach occurred during the 3,600-year period prior to European settlement. A regional climatic shift to somewhat cooler conditions around 4.000 years ago (Winkler and Sanford. 1997: Winkler. 1996) may have contributed to an episode of sedimentation in the transitional main stem. As mentioned earlier. changes in climatic conditions that affect the amount and intensity of runoff can cause changes in channel characteristics. (Cooler temperatures result in less evaporation and more runoff.)

In the lower main stem, approximately 1 to $2 \mathrm{~m}$ of post-settlement sediment accumulated on the flood plain and on the channel bed of North Fish Creek. The WDNR/A shland site (fig. 5) is at the downstream end of the North Fish Creek valley proper and at the beginning of Fish Creek Slough. A valley transect from this site is used as an example to show the distribution and thickness of post-settlement sediment across the flood plain (fig. 17). The core data also show that the post-settlement 


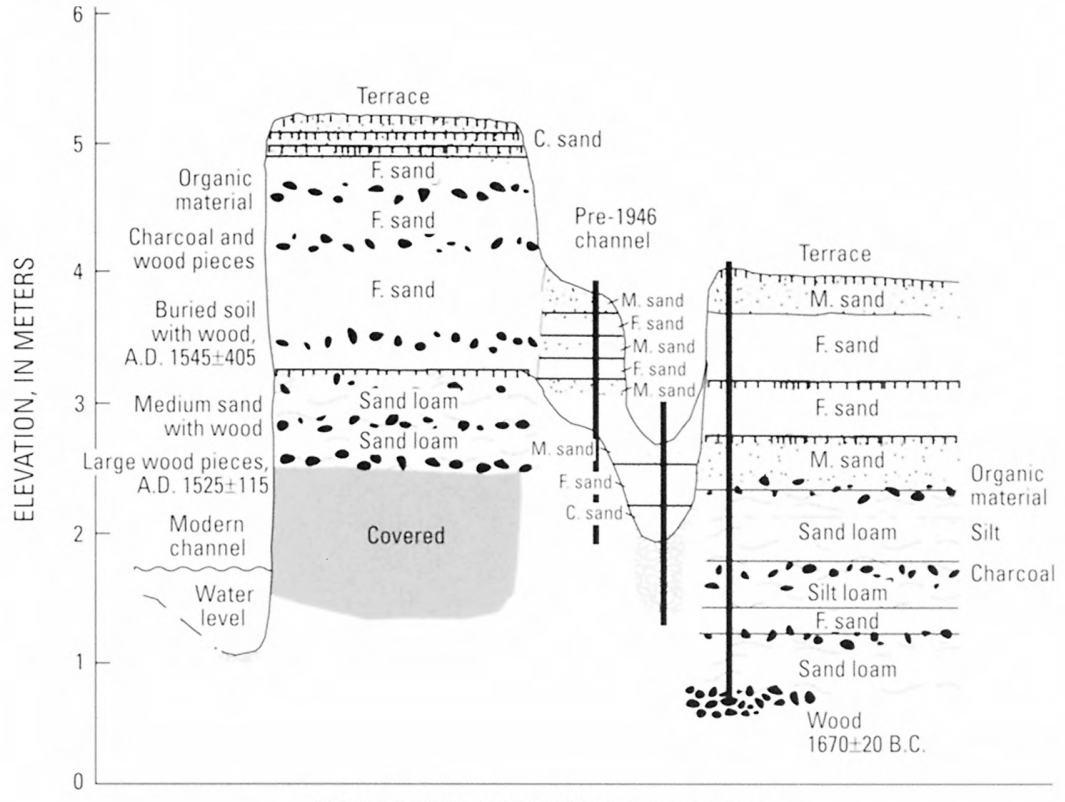

(HORIZONTAL DISTANCE NOT TO SCALE)

EXPLANATION

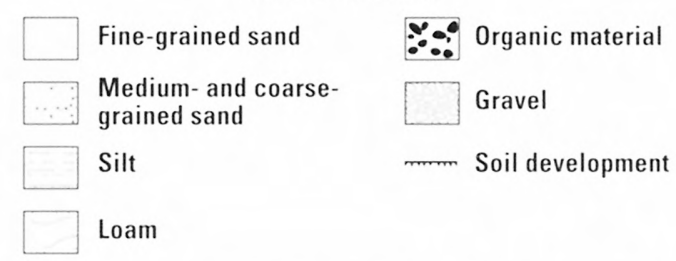

Figure 16. Partial valley cross section of North Fish Creek at the Skulan site, transitional main stem.

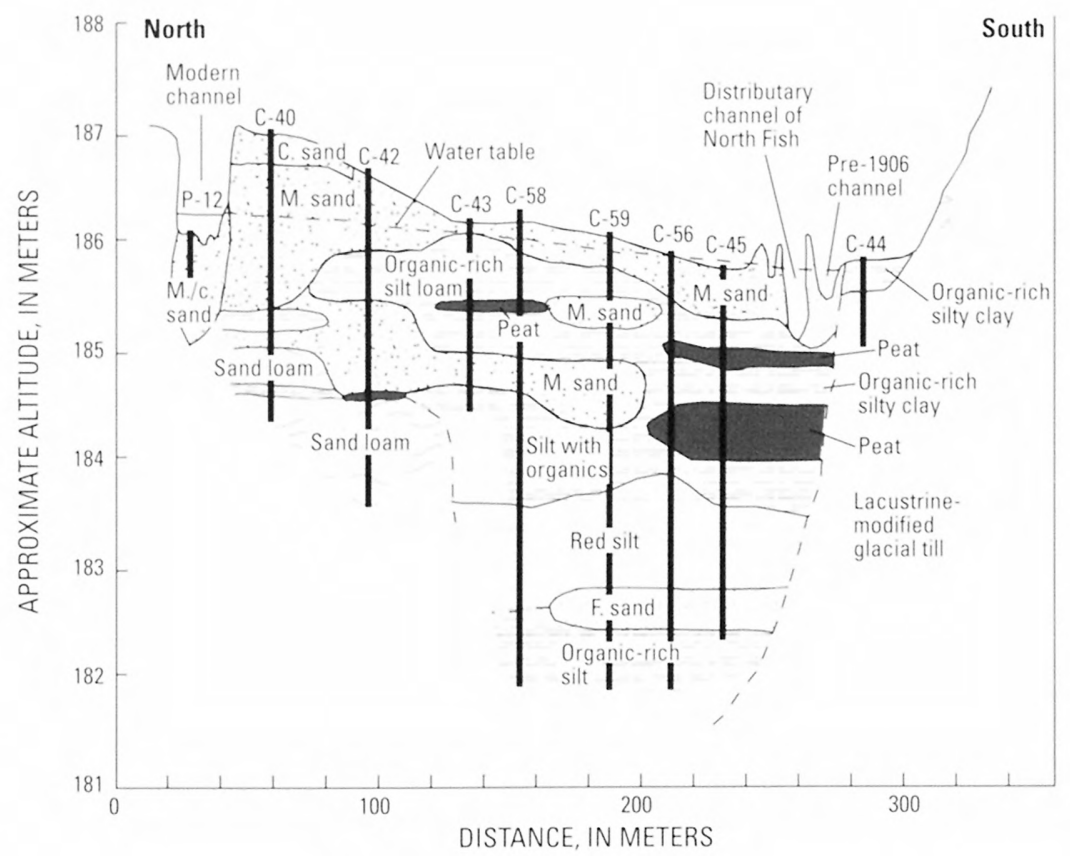

EXPLANATION

$\square$ Fine-grained sand
$\begin{array}{lll}\square & \text { Loam } \\ \square & \begin{array}{l}\text { Medium- and coarse- } \\ \text { grained sand }\end{array} \\ \square & \text { Silt } & \text { Peat } \\ \square & \text { Glacial till }\end{array}$

Figure 17. Stratigraphic descriptions of cores from a valley transect along the lower main stem at the WDNR/Ashland site. sediment deposited in the flood plain is much coarser than that deposited in the flood plain prior to European settlement. Postsettlement deposits consist of medium to fine sand, whereas pre-settlement deposits were generally dominated by silt or clay-rich sediment high in organic content. The pre-settlement flood-plain surface is 1.1 to $1.7 \mathrm{~m}$ below the modern flood-plain surface near the modern channel. The main stem of North Fish Creek branches into multiple channels near this site, causing sediment (mainly sand) to be distributed throughout the flood plain. For example, near a 1906 channel $300 \mathrm{~m}$ south of the main channel, approximately $0.5 \mathrm{~m}$ of postsettlement sediment has been deposited, presumably originating from the nearby distributary channel of North Fish Creek (fig. 17).

Water-table elevations in cores along the WDNR/Ashland transect indicate a water-table gradient of approximately 3 $\mathrm{cm} / \mathrm{m}$ that slopes away from the modern channel and toward the abandoned 1906 channel (fig. 17). As the modern channel continues to fill with sediment at an accelerated rate, the water-table gradient between the modern channel and abandoned or spring-fed channels continues to steepen, which in turn increases the potential of North Fish Creek to move into deep. spring-fed channels in Fish Creek Slough.

Core data collected near the confluence of North and South Fish Creeks in Fish Creek Slough (fig. 11, G-7) indicate that approximately $1.8 \mathrm{~m}$ of post-settlement sediment, mainly fine sand, has accumulated on the flood plain surface at a location $20 \mathrm{~m}$ from the modern channel (fig. 18). Radiocarbon ages of wood samples from buried soils below the pre-settlement soil indicate that the post-settlement sedimentation rate of $1.4 \mathrm{~cm} /$ $\mathrm{yr}$ at this site is 5 times greater than the average rate of $0.28 \mathrm{~cm} /$ yr during the 500 years preceding European settlement. Particle-size data (fig. 18) indicate an increase in the sand content of post-settlement flood-plain deposits compared to silt and clay-rich pre-settlement deposits. Percentages of organic carbon increase near the modern flood-plain surface, indicating a relatively recent decrease in flood-plain sedimentation. (Organic material from flood-plain vegetation is easily diluted by sediment deposition or removed by flood flows.)

The position of the outlet of Fish Creek into Chequamegon Bay changed significantly after European settlement (fig. 11). There are two modern outlets from the slough into Chequamegon Bay. The western outlet is the primary outlet of flow from Fish Creek. The eastern outlet of the slough is approximately $1 \mathrm{~km}$ east of the modern outlet of Fish Creek. Sandy sediment is mainly confined to channels that feed from Fish Creek in the western part of Fish Creek Slough, whereas the spring-fed channels and back water areas in the eastern part of the slough are mainly characterized by silt and clay. In the eastern slough, sandy streambed sediment is found only in the channel of Fish Creek abandoned around 1920. Water depths in the modern channel of Fish Creek in the slough tend to be less than $0.5 \mathrm{~m}$, whereas springfed channels flowing into the eastern slough are more than $1 \mathrm{~m}$ deep. Approximately 0.5 to $1.5 \mathrm{~m}$ of post-settlement medium to very coarse sand has accumulated in the modern channel of Fish Creek near the mouth of Fish Creek in Fish Creek Slough. Dense silt and clay with variable amounts of organic debris underlie the sand filling the modern channel. The fine-grained sediment probably represents pre-settlement backwater sediment deposited when the mouth of Fish Creek was $1.5 \mathrm{~km}$ east of its present location. 


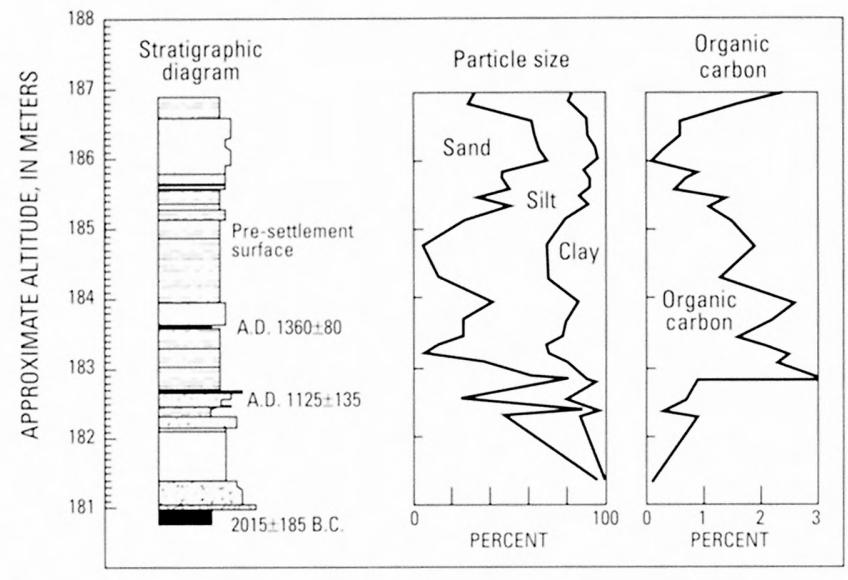

Figure 18. Stratigraphic description of core G-7 near the confluence of North and South Fish Creeks, Fish Creek Slough.

Geomorphic evidence indicates that the elevation of the water table near the downstream end of the lower main stem and in Fish Creek Slough has increased. In the lower main stem, the increase is probably caused by a combination of flood-plain and channel sedimentation; and in Fish Creek Slough the increase is probably caused by the slight rise in base level from crustal rebound. Evidence for a rising water table at the WDNR/Ashland site is provided by a root crown of a large stump, identified as elm species (Ulmus). which is now at the current water level in an abandoned channel at this site. In Fish Creek Slough, soils near the confluence of North and South Fish Creeks are mapped as being subject to frequent flooding; they have poor potential for cultivated crops, hay, or pasture, but they are suitable for wetland wildlife habitat (Pratt. 1981). In contrast, 250 years ago the confluence of North and South Fish Creeks was the site of "a large and populous Indian village of the Ottawas, who there raised Indian corn" (Thwaites, 1895, p. 430). The presence of woody debris (tree trunks and branches) under approximately $30 \mathrm{~cm}$ of water in the back water areas of Fish Creek Slough also point to an increase in the level of Lake Superior relative to the land surface. Pratt (1981) indicates that the amount of open marsh in the slough has increased possibly twofold since the 1855 GLO surveys.

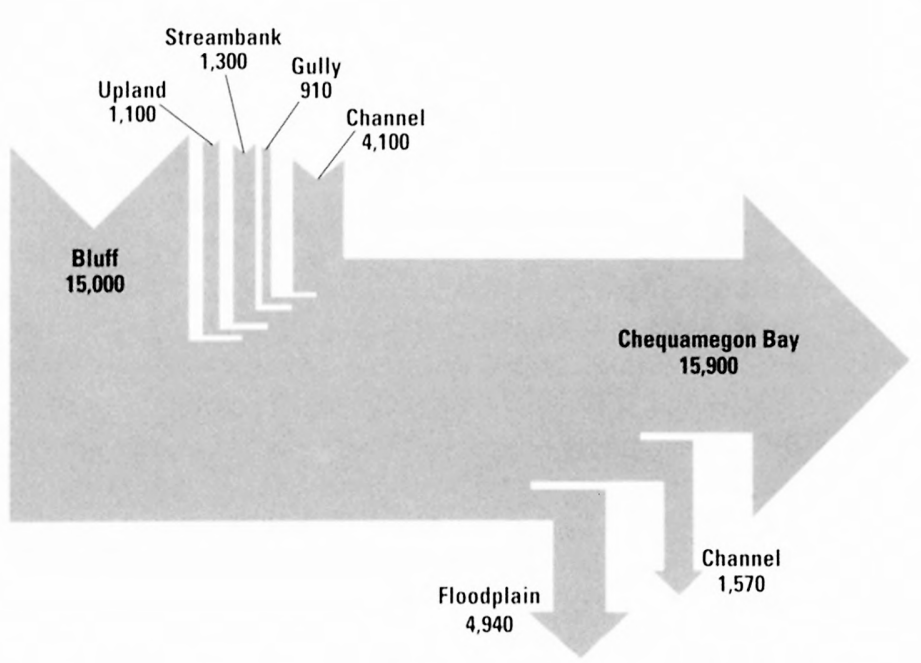

Figure 19. Historical annual sediment budget for North Fish Creek near Moquah and near Ashland Junction, Wis. (All inputs and outputs are in tonnes per year).

\section{Overall Channel Adjustments}

Overall channel adjustments along the main stem of North Fish Creek are illustrated in two ways: (1) by a post-settlement sediment budget and (2) by overall changes in the longitudinal profile along the main stem. The post-settlement annual sediment budget for North Fish Creek at the mouth (fig. 19) shows the sources and sinks of sediment in North Fish Creek. Except for upland erosion rates, which were estimated from sediment-load data from Rose and Graczyk (1996), this budget relies on post-settlement erosion and sedimentation rates derived from geomorphic field data (Fitzpatrick, 1998). Annual variations in erosion and deposition are highly dependent on the size of floods during each year. Post-settlement inputs of sediment from erosion in the upper and transitional main stem (22.000 tonnes) are greater than longterm outputs to Chequamegon Bay (15,900 tonnes) because of longterm sediment deposition in the flood plain and channel along the lower main stem. The sediment budget again illustrates the overwhelmingly large contribution of sediment from bluff erosion along the upper main stem.

Estimated longitudinal profiles for North Fish Creek over the last 4,000 years indicate how the elevation of the main stem has changed in response to natural changes in climate and base level before European settlement and to human changes in land cover after European settlement (fig. 20). Near the mouth of Fish Creek, the amount of channel sedimentation caused by land-cover changes over the 125 years after European settlement is about equal to that caused mainly by an increase in base level over 4,000 years before European settlement.

\section{IMPLICATIONS FOR FUTURE MANAGEMENT ACTIVITIES}

Modern inputs of sediment from North Fish Creek to Lake Superior may be as much as 2.5 times higher than pre-settlement rates because of the long-term response of channel downcutting in the upper main stem that was initiated by clearcut logging and burning, accelerated by agricultural land use, and maintained by accelerated runoff associated with deforestation. This rate may have been as much as 5 times higher in the 70 years after European settlement because of logging and more intense agricultural activity. Depending on the position of the channel along the main stem, overbank and channel sedimentation rates may have been 9 times higher than pre-settlement rates, especially within the sensitive transitional zone between upper (erosional) and lower (depo-

Figure 20. A comparison of the modern (A.D. 1995) North Fish Creek longitudinal profile with profiles from A.D. 1870 and approximately 2,000 B.C.

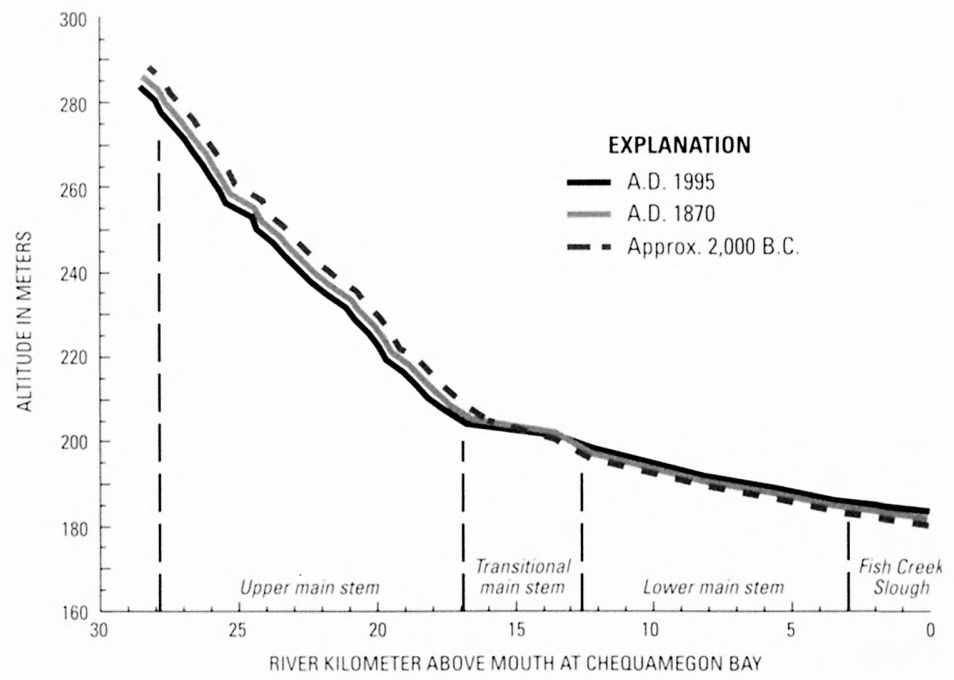


sitional) main stems. The exact geomorphic effects of clearcut logging and log driving on North Fish Creek could not be separated from the effects of agricultural activity because agriculture immediately followed clearcut logging. A few available photographs, however, indicate that streambanks along the lower main stem stabilized within a few decades after the log drives.

In general, the texture of streambed sediment in North Fish Creek has not changed during historical time. The stability of the channel bed, however, has changed. The accelerated channel sedimentation rates and shifting sand bottom have resulted in the filling of scour holes, loss of aquatic-plant beds, and loss of fish habitat. These effects are most noticeable in the transitional and lower main stem.

The effects of land cover on channel characteristics of North Fish Creek were especially noticeable after large rainfalls and floods. From about 1910 to 1940, when agricultural activities in the basin were at their peak, large rainfalls were few and far between (fig. 8). Two of the three largest rainfalls on record, however, occurred within 5 years of each other (1941 and 1946) and were followed by a cluster of large floods in the early 1950's. This episode of large floods over about 15 years resulted in the most change in channel conditions in North Fish Creek on the basis of geomorphic field data and historical accounts. Thus, there may have been a delayed response in channel conditions of about 30 years or more between peak agricultural activity and the time when channel conditions actually reflected peak agricultural activity. The possibility of a delayed response in channel conditions after a change in land cover implies that short-term climatic conditions need to be examined in the context of long-term climatic variability for proper interpretation of cause and effect relations between land cover and channel conditions.

Sedimentation rates and flood peaks have potentially decreased since the 1940's with a decrease in the extent of agricultural activity: however, entrenched channels and floods larger than those during presettlement time continue to promote streambank and bluff erosion and channel instability in the upper and transitional main stems. Minimal streambank erosion in the lower main stem provides only local sources of sediment (fig. 19). Thus, management and restoration activities would be most effective if they focused on drainage-basin practices that reduce runoff and on channel restorations that reduce bluff and streambank erosion in the upper and transitional main stems. Channelrestoration or bank-stabilization efforts along the lower main stem would result in only local benefits at best because they would not affect the direct causes of the flooding and sedimentation problems.

Returning the vegetation in the drainage basin to its pre-settlement forested state would reduce the amount of storm runoff, peak flows, and related bluff erosion. Rainfall/runoff and sediment-load modeling results indicate that the construction of detention basins in upper tributaries may also reduce peak flows and related bluff erosion (fig. 14). Another alternative for reducing erosion and sedimentation along North Fish Creek is to stabilize eroding bluffs along the upper main stem and thereby potentially reduce the largest source of sediment. The toe of the bluffs most prone to erosion could be stabilized through bank protection. Bluff erosion also may be reduced by placement of structures in the channel that would reduce the lateral flow of water against the toe of a bluff. Alternatively, the modern channel could be relocated away from the eroding bluff face.

Northern Wisconsin streams such as North Fish Creek are typically used as baseline reference sites because they are presumed to represent nearly natural conditions. Although the effects of human activity are less in the North Fish Creek Basin than in other, more agriculturally dominated basins elsewhere, the results from this study indicate a strong human influence on the stream's geomorphology and hydrology. Nevertheless, geomorphic and modeling data both indicate that the size of floods and sedimentation rates were markedly reduced as the intensity of agriculture decreased over the past several decades. As a result, aquatic habitat has the potential to improve. Long-term monitoring of streamflow, sediment loads, channel conditions, and aquatic habitat would be useful for determining how channel conditions and aquatic habitat adjust to future land-cover changes or management efforts.

\section{REFERENCES CITED}

Baker, V.R., and Costa, J.E., 1987. Flood power, in Mayer, L., and Nash. D., eds., Catastrophic flooding: Proceedings from the 18th Binghamton Symposium. Boston, Allen and Unwin, p. 1-21.

Finley, R.W.. 1976, Original vegetation of Wisconsin: Wisconsin Geological and Natural History Survey Map, scale 1:500,000, 1 sheet.

Fitzpatrick, F.A.. 1998, Geomorphic and hydrologic responses to vegetation, climate, and base level changes, North Fish Creek. Wisconsin: Madison, Wis.. Geography Dept., University of Wisconsin-Madison, Ph.D. dissertation, 275 p.

Fitzpatrick, F.A., Waite, I.R., D'Arconte, P.J., Meador, M.R., Maupin, M.A., and Gurt/, M.E., 1998, Revised methods for characterizing stream habitat in the National Water-Quality Assessment Program: U.S. Geological Survey WaterResources Investigations Report 98-4052,67 p.

Hershfield, D.M., 1961. Rainfall frequency atlas of the United States: U.S. Weather Bureau Technical Paper 40.

International Joint Commission, 1976, Further regulation of the Great Lakes: International Joint Commission Report to the Governments of Canada and the United States, 96 p.

Jacobson, R.B., and Primm. A.T., 1997. Historical land-use changes and potential effects on stream disturbance in the Ozark Plateaus, Missouri: U.S. Geological Survey Water-Supply Paper 2484, 85 p.

Johannes, S.I., Sather, L.M., and Threisen, C.W., 1970, Surface-water resources of Bayfield County: Wisconsin Department of Natural Resources report. 372 p.

Knox, J.C., 1977. Human impacts on Wisconsin stream channels: Annals of the Association of American Geographers, v. 67, no. 3, p. 323-342.

1983. Responses of river systems to Holocene climates, in Wright, H.E., Jr., ed., Late Quaternary environments of the United States, v. 2. The Holocene: Minneapolis. University of Minnesota Press, p. $26-41$.

1984. Fluvial responses to small scale climate change, in Costa. J.E., and Fleisher, P.J., eds., Developments and applications of geomorphology: Berlin. Springer-Verlag. p. 318-343.

Krug. W.R., Conger, D.H., and Gebert. W.A. 1992. Flood-frequency characteristics of Wisconsin streams: U.S. Geological Survey Water-Resources Investigations Report 91-4128. $185 \mathrm{p}$.

Larsen, C.E., 1985, Geoarchaeological interpretation of Great Lakes coastal environments, in Stein. J.K.. and Farrand. W.R.. eds., Archacological sediments in context. peopling of the Americas, v. 1: Center for the Study of Early Man, University of Maine at Orono. Institute for Quaternary Studies, p. 91-110.

1994. Beach ridges as monitors of isostatic uplift in the upper Great Lakes: Journal of Great Lakes Research, v. 20, n. 1. p. 108-134.

Leopold, L.B., and Maddock, T., 1953, The hydraulic geometry of stream channels and some physiographic implications: U.S. Geological Survey Professional Paper $252.57 \mathrm{p}$.

Leopold, L.B., Wolman, M.G., and Miller, J.P.. 1964, Fluvial processes in geomorphology: San Francisco, W.H. Freeman and Co., 522 p.

Lillesand, T., Chipman, J., Nagel, D., Reese, H., Bobo, M., and Goldmann. R., 1998. Upper Midwest Gap analysis program image processing protocol: U.S. Geological Survey Environmental Management Technical Center. EMTC 98-G001. $25 \mathrm{p}$.

Ludman, A., and Coch, N.K.. 1982. Physical geology: New York. McGraw-Hill Book Co., 587 p.

Mahaffey, C.G., and Bassuk, F.R., 1978, Images of the cutover-a historical geography of the resource utilization in the Lake Superior region, 1845-1930: University of Wisconsin-Madison, Institute for Environmental Studies Report 98, $38 \mathrm{p}$.

Natural Resources Conservation Service and U.S. Forest Service, 1998. Executive summary report-erosion and sedimentation in the Nemadji River Basin: Nemadji River Basin Project, 16 p. 
Pratt. D.M. 1981. Environmental and public use inventory of the Fish Creek Slough Project Area: Wisconsin Department of Resources, unpublished report / variously paged].

Reinhart. K.G.. Eschner. A.R.. and Trimble. G.R., 1963. Effect on streamflow of four forest practices in the mountains of West Virginia: U.S. Forest Service Research Paper NE-1. 79 p

Robertson, D.M.. 1996, Use of frequency-volume analyses to estimate regionalized vields and loads of sediment. phosphorus, and polychlorinated biphenyls to Lakes Michigan and Superior: U.S. Geological Survey Water-Resources Investigations Report 96-4092, 47 p.

Rose. W.. and Graczyk. D.. 1996. Sediment transport, particle size. and loads in North Fish Creek in Bayfield County. Wisconsin, water years 1990-91: U.S. Geological Survey Water-Resources Investigations Report 95-4222. 18 p.

Schumm, S.A., 1977. The fluvial system: New York. Wiley and Sons, 338 p.

Schumm. S.A., and Lichty. R.W. 1963, Channel widening and flood-plain construc tion along Cimarron River in southwestern Kansas: U.S. Geological Survey Professional Paper 352-D. p. 71-88.

Stuiver. Minze, and Reimer, P.J.. 1993. Extended 14 C data base and revised CAL.IB 3.() $14 \mathrm{C}$ age calibration program: Radiocarbon. v. 35, no. 1. p. 215-230.

Thwaites. R.G., 1895. The story of Chequamegon Bay: Collections of the State Historical Society of Wisconsin, v. 8, p. 397-440.

Turner, J.M., and Company, 1889, Lake Superior Region Illustrated, Part 1: J.M Turner and Company [variously paged].

Turner, L.J., and Turner, J.M., 1898, Handbook of Wisconsin, its history and geography: Burlington. Wisconsin, Lura J. and J.M. Turner |variously paged)

\section{CONVERSION FACTORS AND ABBREVIATIONS}

\begin{tabular}{lcl}
\hline Multiply & By & To obtain \\
\hline centimeter $(\mathrm{cm})$ & 0.3937 & inch \\
meter $(\mathrm{m})$ & 3.2808 & foot \\
kilometer $(\mathrm{km})$ & 0.6214 & mile \\
square kilometer $\left(\mathrm{km}^{2}\right)$ & 0.3861 & square mile \\
cubic meter per second $(\mathrm{cms})$ & 35.314 & cubic foot per second \\
tonne & 1.10229 & ton
\end{tabular}

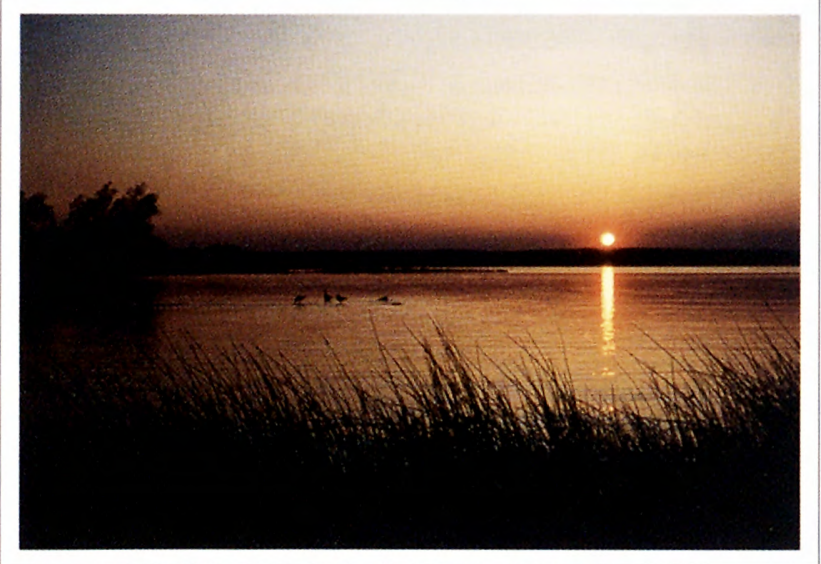

Chequamegon Bay near the mouth of Fish Creek, Ashland, Wis.
U.S. Army Corps of Engineers. 1990). HEC-1-Flood hydrograph package-User's manual: U.S. Army Corps of Engineers, Hydrologic Engineering Center, Version 4.0. Sept. 1990 [variously paged]

1991, HEC-2 water surface profiles user's manual, September, 1990: U.S. Army Corps of Engineers, Hydrologic Engineering Center CPD-2A [variously paged].

U.S. Department of Commerce. 1973. Hydrograph of monthly mean levels of the Great Lakes: U.S. Department of Commerce, NOAA-National Ocean Survey, Lake Survey Center, 1 oversized sheet.

Verry. E.S.. 1987. The effect of aspen harvest and growth on water yield in Minnesota: Forest Hydrology and Watershed Management. Proceedings of the Vancouver Symposium. August 1987. p. 553-562

Williams, G.P.. 1978. Bankfull discharge of rivers: Water Resources Research. v. 14. no. 6. p. $1141-1154$.

Winkler. M.G.. 1996. The paleoecology and pH history of Ike Walton Lake and comparison with the recent history of Zee Lake: Madison. Wis.. Center of Climatic Research. University of Wisconsin. Final Report to the Lac Du Flambeau Water Resources Program. 22 p.

Winkler. M.G., and Sanford. P.R., 1997. Paleolimnological research at Isle Royale. A postle Islands and Voyageurs National Parks: Summary Report. Western Great Lakes Biogeographic Area, p. 30-33

Wisconsin Department of Agriculture and Wisconsin Geological and Natural History Survey, 1928, Land economic inventory, Bayfield County. Wis.-Forest form and cover maps: scale 1:63.360

Wolman, M.G.. and Leopold, L.B., 1957. River flood plains-some observations on their formation: U.S. Geological Survey Professional Paper 282-C. p. 87-109

\section{Acknowledgments}

Project development: Bruce Swanson, Dennis Pratt-Wisconsin Department of Natural Resources; William Rose, David Graczyk-USGS.

Land access: Mr. and Mrs. Fiorio, Betty Hanson, the Johaniks, the Martinsens, the Mihaleks, the Moores, the Palmers, and David Skulan.

Data collection and analyses: John Attig, Ross Bagwell, Richard Baker, William Becker, Reid and Robert Bryson, Thomas Cogger, Brian Dalsing, Suzanne Femmer, William Fitzpatrick, Steven Gaffield, Michael Gardner, Scott Hulse, Robert Jarrett. Diann Kiesel, Christopher Kent, Keith Ligler, David McJunkin, David Mickelson, Richard Mihalek, Kenneth Potter, Bruce Rapps, Ty Sabin, Todd Stuntebeck, Sam Veda "Fish Creek Sam", Marjorie Winkler, and Herbert Wright.

Report layout: Michelle Greenwood_-USGS

Editorial and technical reviews: William Rose-USGS: Barbara Lensch-Natural Resources Conservation Service; Michael Eberle and Betty Palcsak-USGS.

For more information on this study, please contact:

Faith Fitzpatrick, U.S. Geological Survey, 8505 Research Way, Middleton, WI 53562 (608) 821-3818.

Professor James Knox, Geography Department, University of Wisconsin-Madison, 550 N. Park St. Madison, WI 53706 (608) 262-1804.

\section{Information}

For more information on USGS publications and activities in

Wisconsin, please contact:

District Chief

U.S. Geological Survey

8505 Research Way

Middleton, WI 53562

(608) 828-9901

USGS WRIR 99-4083

www: http://wi.water.usgs.gov/ 